\title{
MHAM- A HISTÓRIA E A CASA DA NOBREZA MARANHENSE DO SÉC. XIX ${ }^{1}$ \\ Giovanna Jansen Duailibe ${ }^{2}$
}

DOI: 10.5752/P.2316-1752.2017v24n34p248

\section{Resumo}

Este artigo trata da edificação que sedia o Museu Histórico e Artístico do Maranhão - MHAM e abriga uma exposição permanente que utiliza seus cômodos para retratar usos e costumes de uma residência nobre maranhense do séc. XIX. Seu objetivo é analisar como costumes da época influenciavam hábitos e espaços de morar e se justifica pela necessidade de compreensão das transformações desses espaços ao longo do tempo. Para tal, serão analisadas sua tipologia e qualificação do espaço interior, com base no método adotado por Costa e Lima (2005) e em levantamento bibliográfico.

Palavras-chave: MHAM, Residências maranhenses, Edificações do séc XIX, Costumes socioculturais.

1. Com o apoio da Fundação de Amparo à Pesquisa e ao Desenvolvimento Científico e Tecnológico do Maranhão - FAPEMA

2. Arquiteta e Urbanista pela UEMA e Designer pela UFMA, Mestre em Engenharia Civil pela UFSC, Doutoranda do Programa de Doutoramento em Arquitetura da ULISBOA, Professora do Departamento de Arquitetura e Design da Universidade Ceuma. Email: giovannajduailibe@gmail.com 
MHAM- THE HISTORY AND THE HOUSE OF MARANHENSE NOBILITY OFTHE 19TH CENTURY

\section{Abstract}

This article deals with the building that hosts the Maranhão Historical and Artistic Museum - MHAM and hold a permanent exposition that uses rooms to depict uses and customs of a 19th century noble residence in Maranhão. The objective is to analyze how customs of this time period influenced habits and living spaces, and is justified by the to understand transformations of theses spaces over time. For this to happen, its typology and interior space qualification will be analyzed based on the method adopted by Costa; Lima (2005) and in a bibliographic search.

Keywords: MHAM, Maranhão residences, 19th century buildings, Socio-cultural Customs.

\section{MHAM- LA HISTORIA Y LA CASA DE LA NOBLEZA} MARANHENSE DEL SIGLO XIX

\section{Resumen}

Este artículo trata la edificación de la sede del Museo Histórico y Artístico de Marañón - MHAM - que abriga una exposición permanente que utiliza sus habitaciones para retratar usos y costumbres de una residencia noble de Marañón del siglo XIX. Su objetivo es analizar cómo las costumbres de la época influenciaban los hábitos y espacios de vivir y se justifica por la necesidad de comprensión de las transformaciones de estos espacios a lo largo del tiempo. Para ello, serán analizadas su tipología y calificación del espacio interior, con base en el método adoptado por Costa; Lima (2005) y en levantamientos bibliográficos.

Palabras-claves: MHAM, Residencias de Marañón, Edificaciones del siglo XIX, Costumbres socioculturales. 


\section{Introdução}

O Solar Gomes de Sousa (figura 1), localizado em São Luís, no Maranhão, cuja arquitetura e distribuição espacial, característicos do século XIX, testemunharam sobre os costumes e modos de vida das famílias nobres e abastadas oitocentistas maranhenses, é um dos mais belos exemplares desse tipo de arquitetura na cidade.

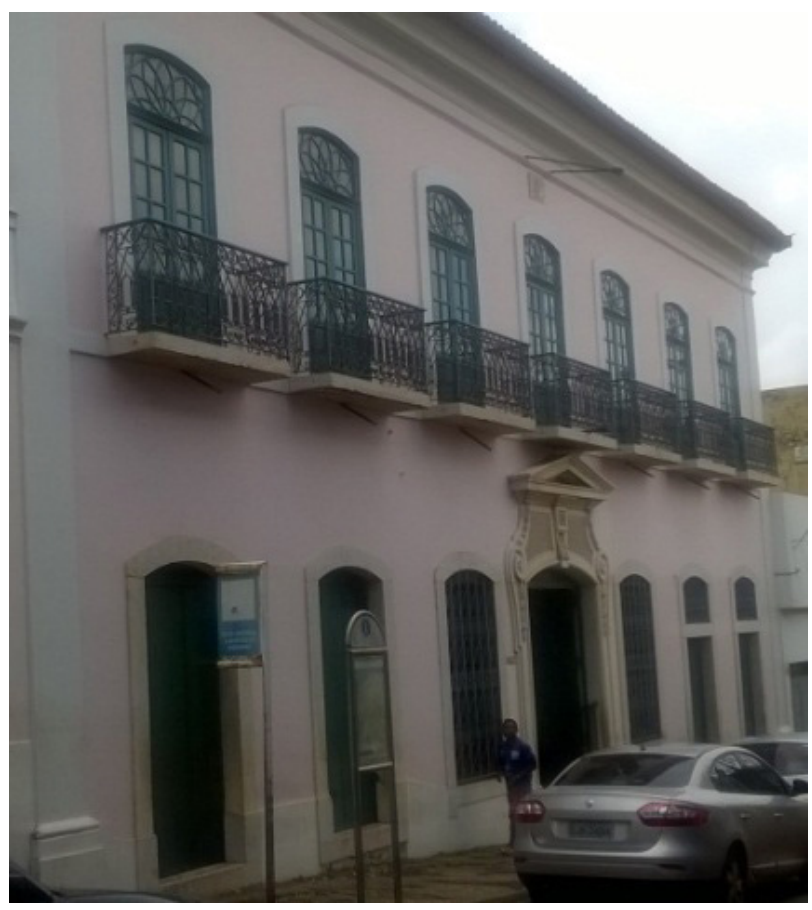

Figura 1 - Fachada do Solar. Fonte: Elaborada pela autora.

Considerado uma referência material e imaterial para a cidade, sua importância cultural e histórica o habilita como 
objeto a ser estudado, pois é importante registrar, de modo mais aprofundado, o uso das edificações do século XIX, a fim de se compreender melhor os hábitos de morar de outrora.

Entretanto, há poucos dados disponíveis publicados sobre o imóvel. Nesse intuito, justifica-se este artigo, cujo objetivo geral é analisar o solar enquanto moradia e, especificamente, identificar os usos de seus espaços e os hábitos de morar que permeavam a ocupação residencial. Ele é parte de uma pesquisa que analisa os hábitos de morar ao logo do tempo e sobre como o tipo de moradia, se oitocentista, moderna ou contemporânea, influencia no desenvolvimento das atividades realizadas no interior dessas habitações pelos moradores, que adaptam as casas mais antigas, considerando seus usos, hábitos e necessidades contemporâneas.

Para análise do solar e das demais edificações estudadas na pesquisa, como em Duailibe (2017), foram utilizados os métodos da pesquisa bibliográfica e a análise adotada por Costa e Lima (2005) a ser explicada mais adiante.

Embora seja uma edificação de arquitetura Pombalina em São Luís, a análise sobre o imóvel não se aprofundará nesse contexto, já realizada em Duailibe (2016), dada a sua excepcionalidade material e imaterial, pois o objetivo deste artigo é estudar a influência de hábitos e costumes nesse tipo de espaço de morar do séc. XIX, mas de maneira a poder 
compará-lo posteriormente, sob os mesmos critérios, com as outras edificações analisadas.

\section{Recorte espacial da edificação em estudo}

O Solar Gomes de Sousa encontra-se na Rua do Sol, número 302, dentro dos limites da Zona do patrimônio Histórico - ZPH - , no centro de São Luís, capital do Maranhão, estado localizado no nordeste do Brasil.

A edificação abriga o Museu Histórico e Artístico do Maranhão - MHAM - e é um monumento tombado pelo governo do estado, através do decreto número 11507 de 1990, e está dentro da área inscrita como Patrimônio Mundial da Humanidade, além de, também, pertencer à área de tombamento estadual e de tombamento federal, esse último, com limite rerratificado em 2013, que hoje se iguala ao limite da área inscrita como Patrimônio Mundial (Figura 2b). A figura 2a a seguir exibe a localização do MHAM, no centro da cidade, com um $X$ vermelho, cujo entorno apresenta vários sobrados do séc. XVIII e XIX, sendo alguns já descaracterizados e/ou em mau estado de conservação. 


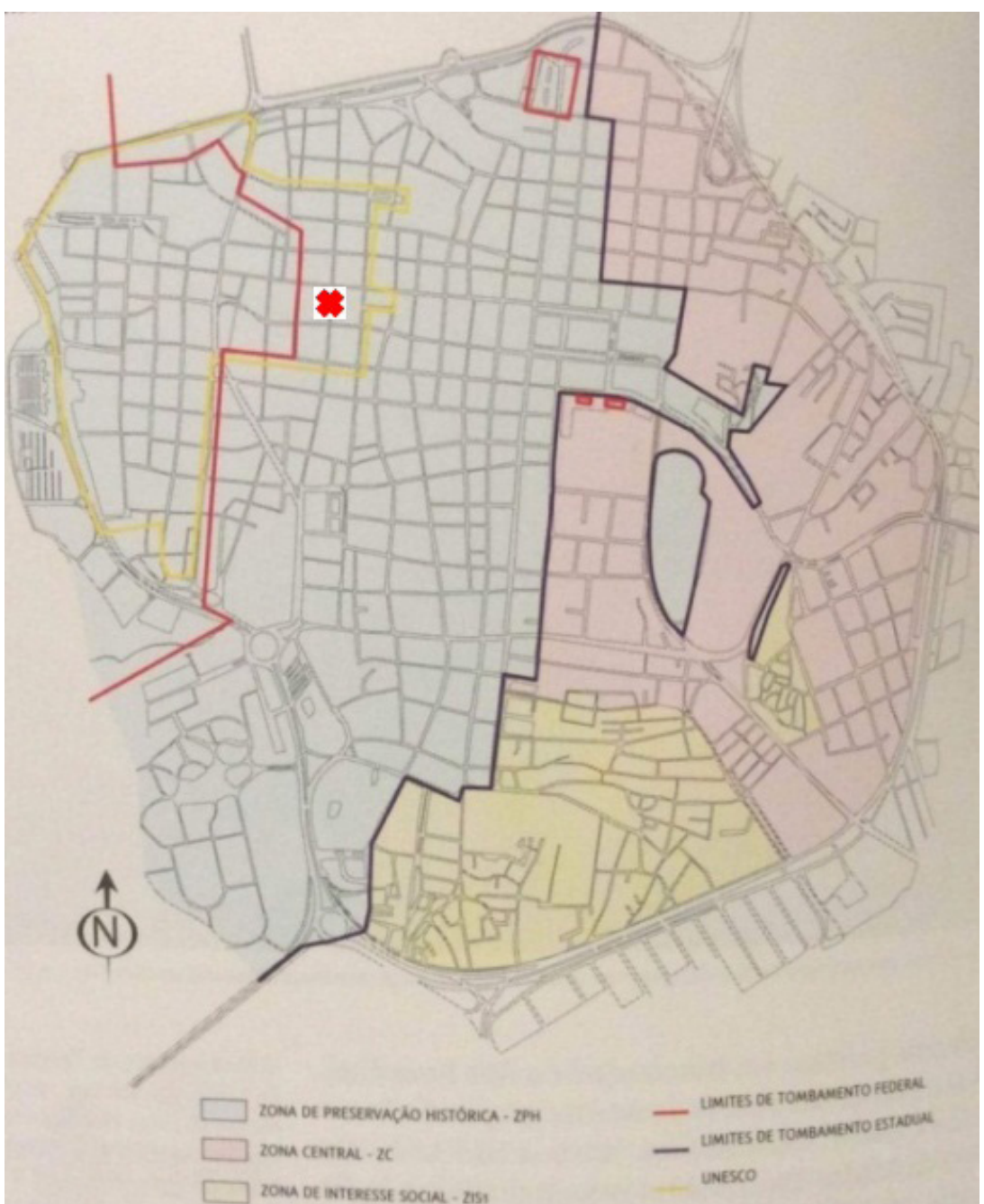




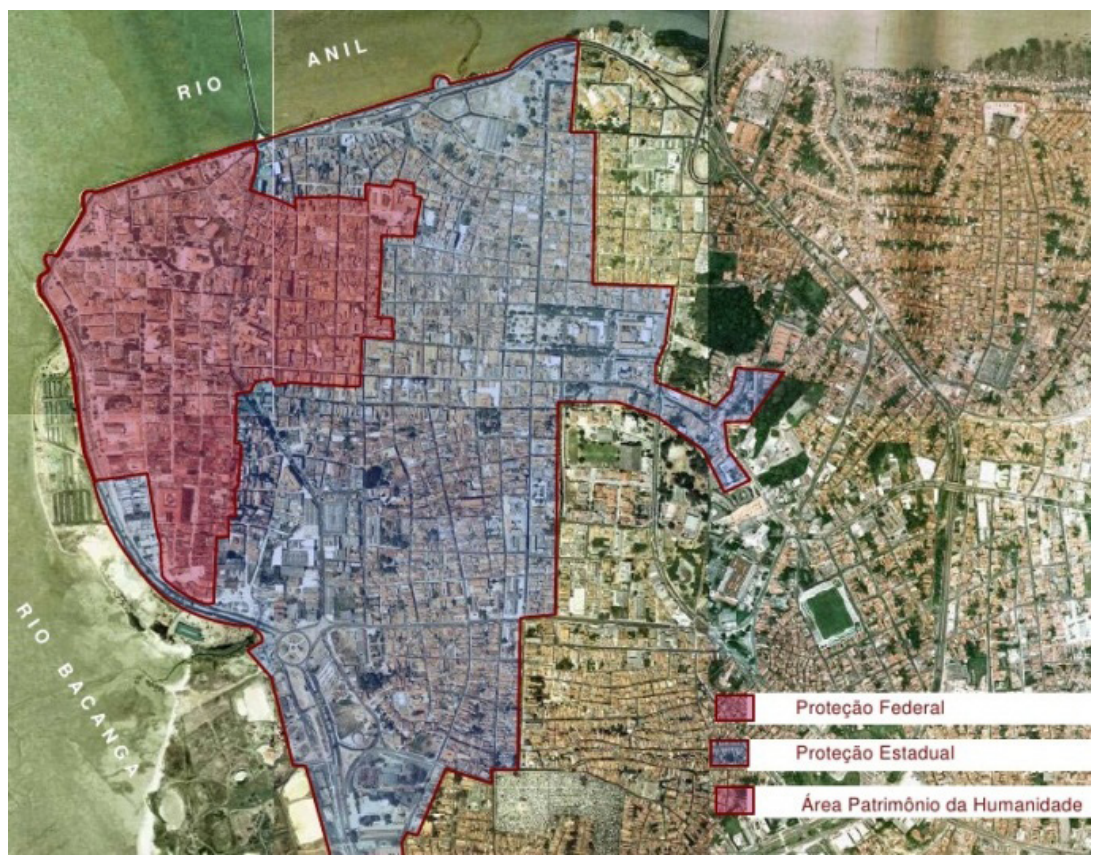

Figura 2b - Zonas e limites após rerratificação da área de tombamento federal. Fonte: Adaptado de São Luís (2008) e Stella Brito.

\section{Contextualização histórica}

Em 1682, 70 anos após a fundação da cidade de São Luís, a Coroa Portuguesa criou a Companhia de Comércio do Maranhão, com a finalidade de aumentar seus ganhos. Mas, de acordo com São Luís (2008), foi a criação da Companhia Geral de Comércio do Grão-Pará e Maranhão, em 1755, pelo Marquês de Pombal, que impulsionou o primeiro dos dois ciclos "responsáveis pelo rápido desenvolvimento da província", entre 1780 e 1820, em razão do cultivo de algodão para abastecer as indústrias da metrópole. O se- 
gundo, entre 1850 e 1870, se deu em razão da produção de açúcar.

O Solar Gomes de Sousa data do ano de 1838, período em que o Maranhão e São Luís prosperavam, resultado da contínua expansão para o interior da ilha do núcleo fundacional da cidade, que começou com a implantação de um plano de arruamento executado por Francisco Frias de Mesquita, engenheiro-mor do estado do Brasil em 1615.

Ele foi construído pelo Major Ignácio José Gomes de Sousa, filho de José Antônio Gomes de Sousa e neto de Antônio Gomes de Sousa. Costa (2013) explica que o português Antônio Gomes de Sousa nasceu em 1710, em Lordelo, Vila Real, mas se mudou para o Brasil, onde foi fazendeiro no estado do Grão-Pará e Maranhão e assumiu diversos cargos políticos.

De acordo com São Luís (2008), lá também residiu seu filho Joaquim Gomes de Sousa, um ilustre intelectual maranhense, que foi pioneiro em estudos matemáticos no Brasil e ainda hoje é considerado um dos maiores matemáticos do país.

De acordo com a Fundação Projeto Rondon (1979), em 1857, o major vendeu o Solar ao Sr. Alexandre Colares Moreira, senador do Brasil durante a chamada república velha e governador do Maranhão de 1902 a 1904. No mesmo ano, o então novo proprietário comprou o terreno ao lado e o transformou em jardim da residência. Portas de acesso e 
janelas laterais foram abertas ligando a casa ao jardim. Essa foi a primeira reforma realizada no Solar, que manteve suas demais características originais.

Santo e; Marcelo (2006) explicam o porquê de muitos casarões no centro histórico de São Luís terem sido preservados:

A manutenção de boa parte do centro antigo e suas imediações com as características originais deu-se pela estagnação econômica da cidade ao fim do séc. XIX o que não permitiu mudanças urbanísticas drásticas nem por parte do poder público, nem privado (SANTO; MARCELO, 2006).

São Luís (2008) relata ainda que Artur e Aluísio Azevedo usaram o teatro da casa para leitura e ensaio de seus trabalhos quando eram jovens.

Em 1918, conforme a Fundação Projeto Rondon (1979), os descendentes do Sr. Alexandre Colares Moreira venderam o imóvel a José Francisco Jorge, grande industrial do setor têxtil do estado e Vice-cônsul da Rússia, Bolívia e Colômbia. Seus herdeiros o venderam ao governo do estado em 1967, que o comprou com a finalidade de transformá-lo em Museu. Nesse mesmo ano, o Solar foi reformado e restaurado para a instalação do MHAM.

O Solar Gomes de Sousa foi, portanto, moradia de descendentes de uma das famílias mais tradicionais e poderosas da sociedade maranhense dos séculos XVIII e XIX, Os 
Gomes de Sousa.

Segundo Mota (2008), um grupo familiar, assim designado, ia além da consanguinidade e coabitação, podendo incluir membros de outras famílias e "relações rituais, como as de compadrio, ou de aliança política".

Costa (2013) completa que eram denominadas "casas" maranhenses os conjuntos familiares que incluíam as linhas diretas de sucessão e suas ramificações genealógicas. Com famílias numerosas, era comum que as edificações pertencentes às "casas" maranhenses abrigassem vários familiares e suas linhagens. Inclusive, era costume que um patriarca, ao deixar em testamento uma edificação a um herdeiro, ordenasse que ainda assim ela deveria continuar recebendo seus descendentes que estivessem de pouso na cidade ou pelo tempo que fosse preciso, dispondo os bens imóveis sob a lógica do conjunto familiar.

Dessa forma, compreendem-se os grandes solares maranhenses com seus inúmeros quartos que abrigavam uma gama de familiares residentes ou de passagem.

Aqui se pode fazer a primeira colocação acerca das transformações vividas pela sociedade brasileira no geral e especificamente a maranhense. Sobre a época correspondente ao período colonial em que as famílias abastadas viviam em fazendas e eram dirigidas sob a forma de clã, cujo patriarca geria todos os seus descendentes e fazia uso de 
suas vidas para ampliar fortunas, por meio de casamentos. Suas casas na cidade refletiam esse poderio patriarcal. Seja no número de cômodos, para alojar a todos, incluindo os escravos, seja na sua composição espacial que precisava "imitar" uma fazenda e suas zonas.

\section{Metodologia}

Para o desenvolvimento desta pesquisa e análise da edificação, foram utilizados como métodos a pesquisa bibliográfica, busca em escritos e vídeos sobre a casa, seu uso, o museu, a arquitetura e o contexto histórico da época em que foi construída e o método de análise utilizado por Costa e Lima (2005), que fizeram uma análise arquitetônica de uma residência moderna na cidade de João Pessoa.

$\mathrm{Na}$ análise do Solar dos Gomes de Sousa, foram considerados, entre outros, os critérios utilizados por Costa e Lima (2005), a fim de explicar os usos dos espaços e os hábitos de morar da época. Além desses critérios, outros pormenores relevantes foram abordados.

Costa e Lima (2005), primeiramente, contextualizaram a edificação a partir da história e do desenvolvimento da cidade para depois analisarem em separado a implantação, composição volumétrica e organização espacial. Neste artigo, embora se tenha usado os mesmos critérios, o que é importante para comparação posterior com o estudo re- 
alizado em outras edificações, a análise desses pontos é feita sob a ótica da história local e dos costumes da época. Além dos pontos abordados pelos autores citados, o mobiliário presente na residência e sua infraestrutura à época foram analisados considerando os modos de vida de outrora, na tentativa de associar esse espaço de morar com os hábitos e costumes não só dos moradores, mas de uma parte da sociedade da época.

A qualidade espacial do interior da edificação e os materiais de acabamento foram abordados em Duailibe (2016).

\section{Análises e resultados}

\section{A localização}

O Solar Gomes de Sousa foi construído no limite da área urbanizada considerada a mais antiga da cidade. A fig. 3 a seguir apresenta o centro histórico da cidade de São Luís, sua expansão ao longo dos séculos e a localização do Solar marcada com um $X$ vermelho.

O terreno

O terreno tem uma área aproximada de $834 \mathrm{~m}^{2}$, sendo $21 \mathrm{~m}$ de testada. A contar com os jardins e anexo dos fundos, o número sobe para $1356 \mathrm{~m}^{2}$. 


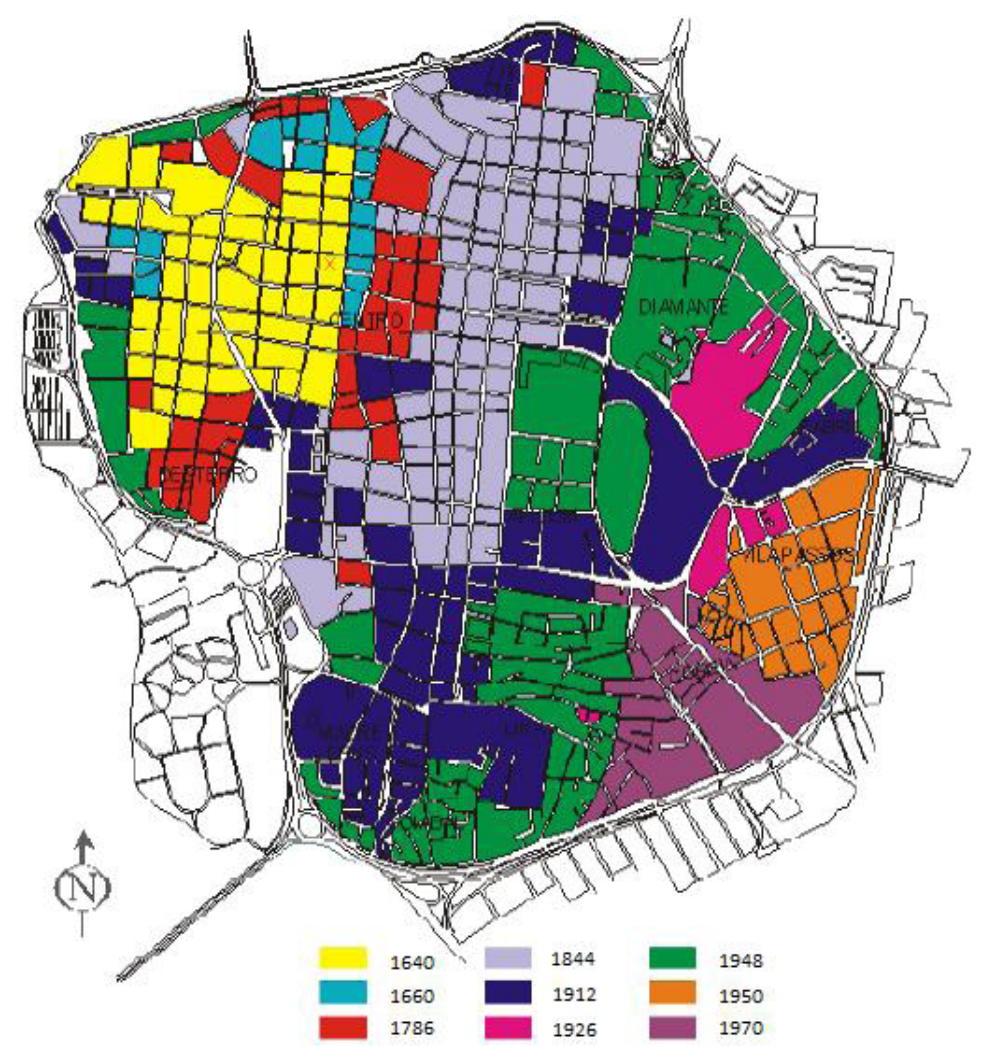

Figura 3 - Evolução/Expansão do Centro Histórico de São Luís: 1640/1970 (sobre base cartográfica de 2001). Fonte: Santo; Marcelo (2006) Apud ESPÍRITO

A implantação

O Solar Gomes de Sousa foi implantado na mesma quadra onde estão o Solar do Barão de Grajaú (outro exemplar da arquitetura pombalina na cidade, também do século XIX) e o prédio da antiga sede da faculdade de Farmácia e Odontologia do Estado, do século XX. Pode-se perceber, também, na figura 4 , a proximidade do imóvel com a igreja de São 


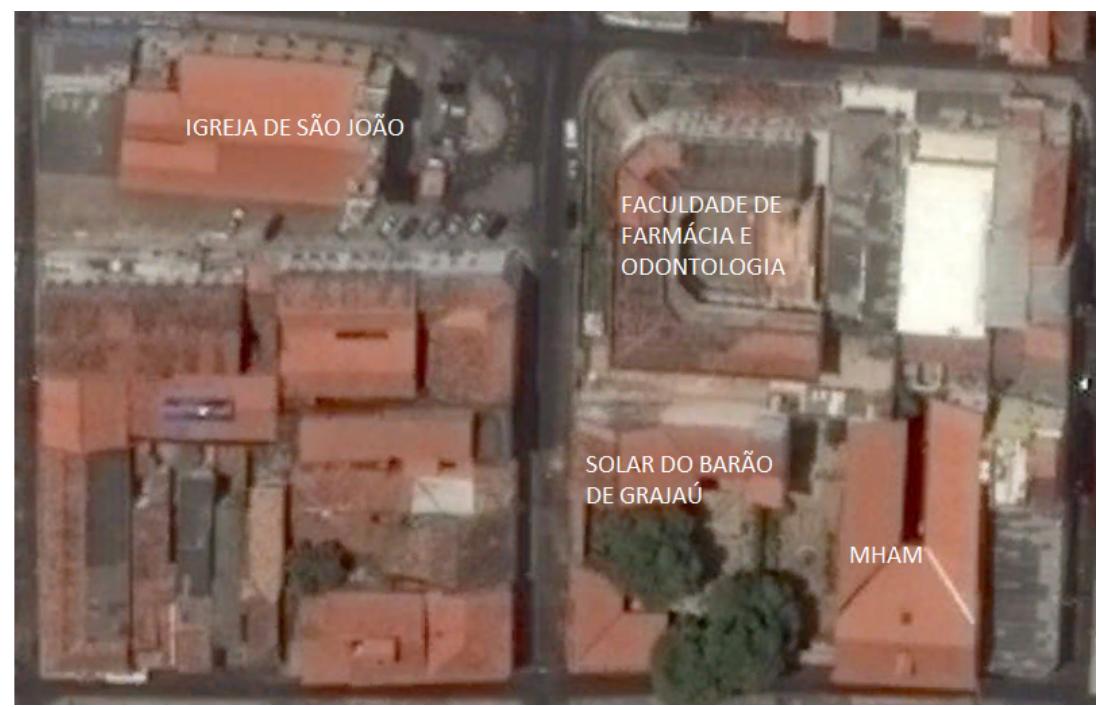

Figura 4 - Imagem aérea da quadra e entorno do Solar Gomes De Sousa. Fonte: Google Earth (grifo da autora).

João, uma das principais e mais antigas da cidade, datada de 1665.

A edificação foi implantada no seu lote em formato de " $U$ ", ocupando todo o limite do terreno original, como pode ser visto na figura 5. Não há recuos frontal e lateral, exatamente como de costume para as casas da época. Posteriormente, os terrenos do Jardim e o dos fundos foram anexados. Atualmente, o jardim lateral é ligado por uma escada ao jardim do Solar do Barão de Grajaú, onde até 2014 funcionou o Museu de Arte Sacra do Maranhão. A figura 5 apresenta as duas edificações, com o MHAM em destaque.

Segundo Silva (2013), essa configuração de uma casa volta- 
da para seu interior e geminada é típica de uma época em que a preocupação com invasões imperava:

Ao analisarmos o traçado urbano de Frias de Mesquita para o núcleo originário de São Luís, observamos uma certa modulação das quadras. Estas podem ser consideradas como verdadeiras fortalezas pois as mesmas são fechadas, não há entrada lateral e o miolo de quadra é que funcionava como uma área de serviço. Além disso, os prédios são geminados e as fachadas são paredes de pedra muito espessas e muito grossas (SILVA, 2013).

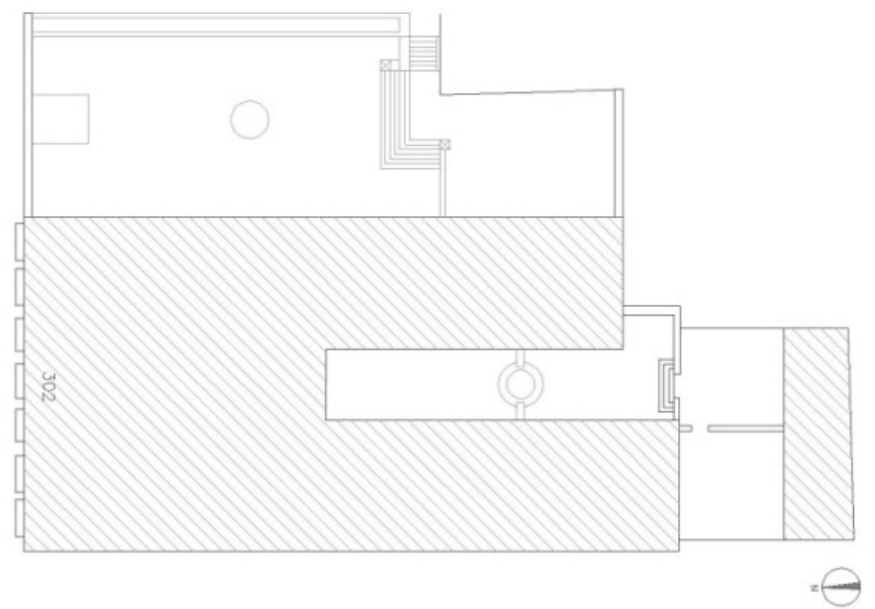

Figura 5 - Planta de Situação do Solar Gomes De Sousa (MHAM) e do Solar do Barão de Grajaú. Fonte: Elaborada pela autora.

Com a fachada frontal voltada para o norte, o terreno encontra-se em posição privilegiada, pois sua frente recebe a ventilação predominante da região, a nordeste. O recebimento desses ventos é favorecido pela segunda fachada, 


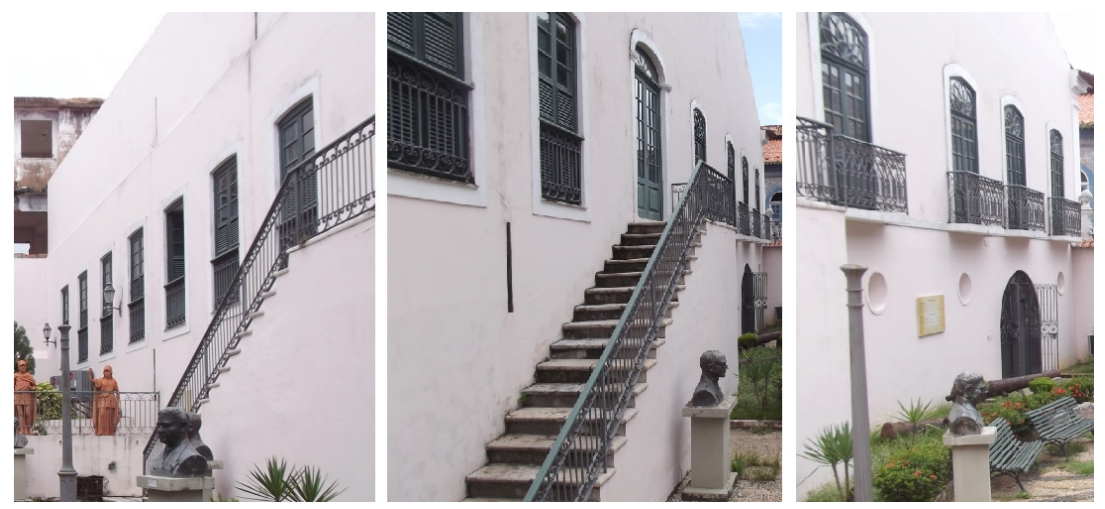

Figura 6 - Montagem com fotos da segunda fachada. Fonte: Elaborada pela

(figura 6) para onde janelas e portas foram abertas, com a aquisição do terreno vizinho pelo segundo morador.

A edificação ocupa $723 \mathrm{~m}^{2}$ do terreno original, alcançando uma taxa de ocupação de 87\%. A área livre, desconsiderando os jardins, é de aproximadamente $104 \mathrm{~m}^{2}$. A alta taxa de ocupação é típica das construções coloniais, quando não havia ainda a exigência de afastamentos, recuos e áreas livres mínimas.

\section{Tipologia e composição volumétrica}

O Solar Gomes de Sousa se encaixa perfeitamente na descrição de Silva (2013), quando este expõe que

os solares eram construções de acabamento requintado, exclusivamente de uso residencial das famílias abastadas... primavam pela suntuosidade e apuro no acabamento, apresentando portadas em pedras de cantaria, algumas de feições neoclássicas com frontões 
triangulares, balcões sinuosos, sacadas em pedra de lioz, com guarda-corpos em gradis de ferro forjado ou fundido em desenhos apurados. Internamente, no pavimento térreo um grande vestíbulo, com piso geralmente decorado em seixo de rio e pedra de lioz dá aceso à escada principal que conduz aos pavimentos superiores onde realmente a família habitava, pois o térreo era destinado a abrigo de carruagens e dependências de serviços (SILVA, 2013).

Segundo Santo e Marcelo (2006), edificações como o Solar em estudo, fruto do desenvolvimento da Companhia de Comércio, seguiram os mesmos princípios hoje reconhecidos como Barroco Pombalino, resultado plástico das medidas

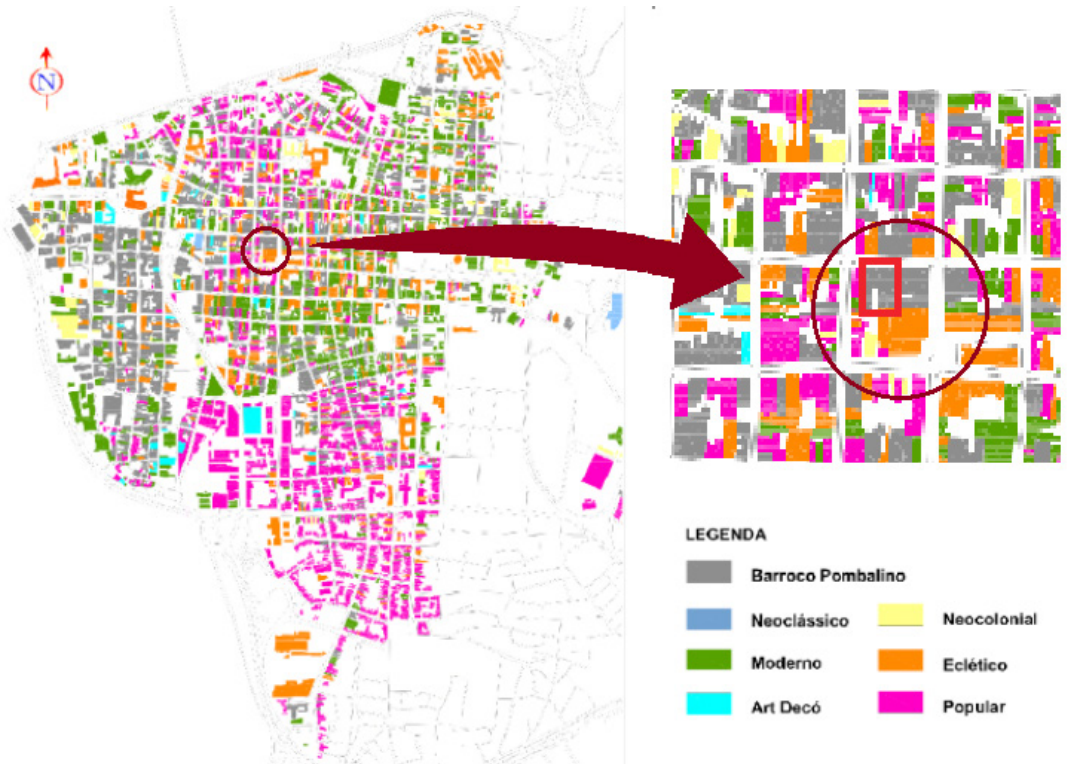

Figura 7 - Levantamento Urbanístico de 98- Centro Histórico de São Luís. 
normalizadoras propostas pela equipe a serviço de Pombal na reconstrução de Lisboa, após o terremoto de 1755 e cujas características foram descritas acima por Silva (2013). A figura 7 a seguir, que exibe um levantamento urbanístico dos estilos arquitetônicos presentes no centro histórico de São Luís, mostra o MHAM, demarcado com um retângulo vermelho, como uma edificação considerada Barroco-Pombalina. O solar está inserido em meio a edificações em sua maioria Barroco-Pombalinas, Ecléticas e Populares.

São dessa época os detalhes construtivos que adaptaram o Barroco Pombalino ao clima quente de São Luís, como o fechamento das varandas em madeira, com rótulas móveis, os forros "espinha de peixe", que permitiam a circulação do ar e o pé direito elevado, que favorecia a ventilação e aumentava a zona de conforto do usuário, todos encontrados no Solar Gomes de Sousa e apresentados por Duailibe (2016).

A edificação possui um único volume, em formato de " $U$ ", de onde se sobressai um pequeno mirante (figura 8).

A fachada ocupa toda a testada principal do lote. É praticamente simétrica, como as construções tradicionais e apresenta a portada com volutas e frontão triangular (figuras 9a e 9b).

As Janelas e portas possuem arcos abatidos emoldurados em cantaria, simetricamente distribuídos. Acima, as sete 


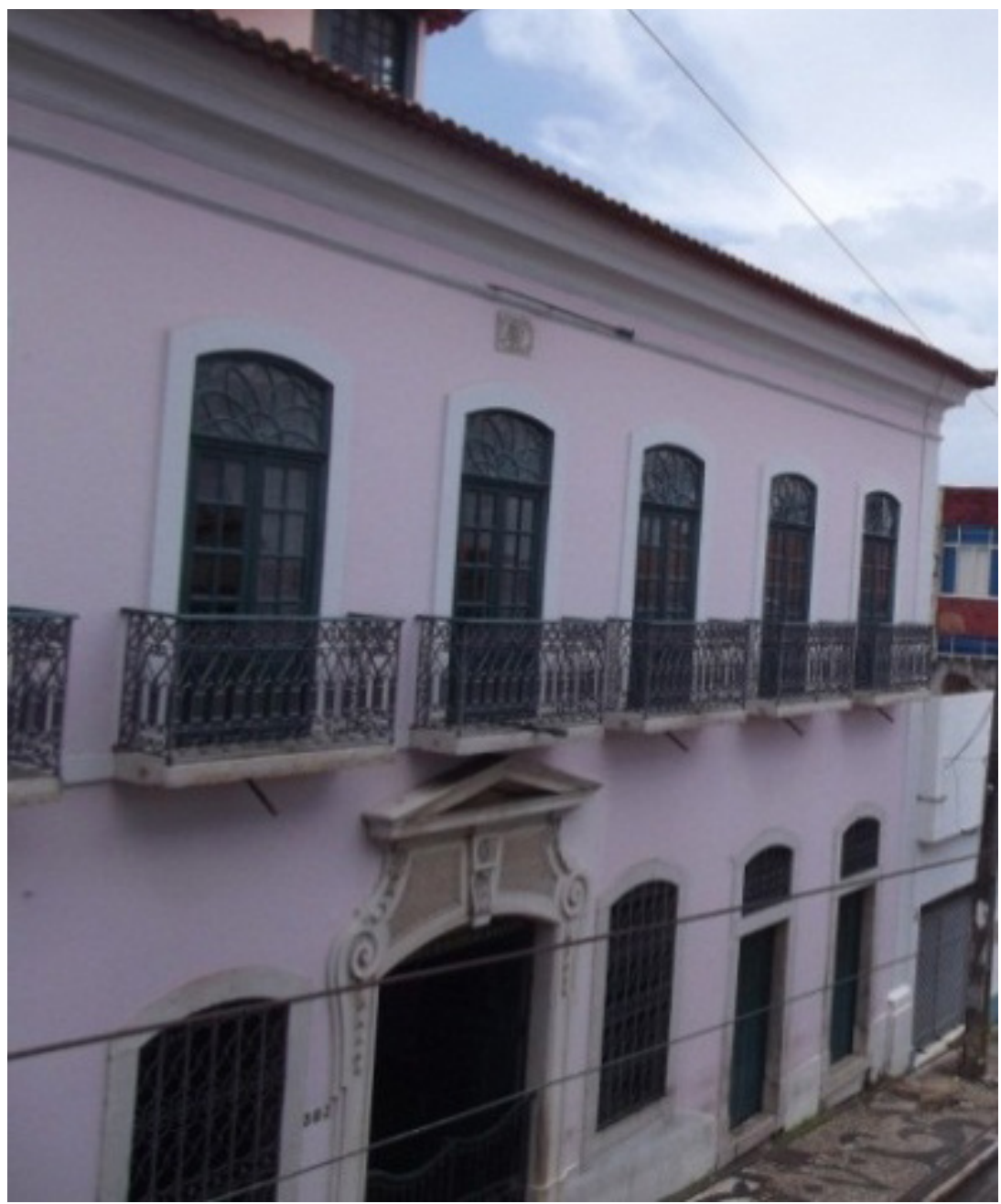

Figura 8 - Fachada do Solar. Fonte: Arquivo pessoal da autora. 


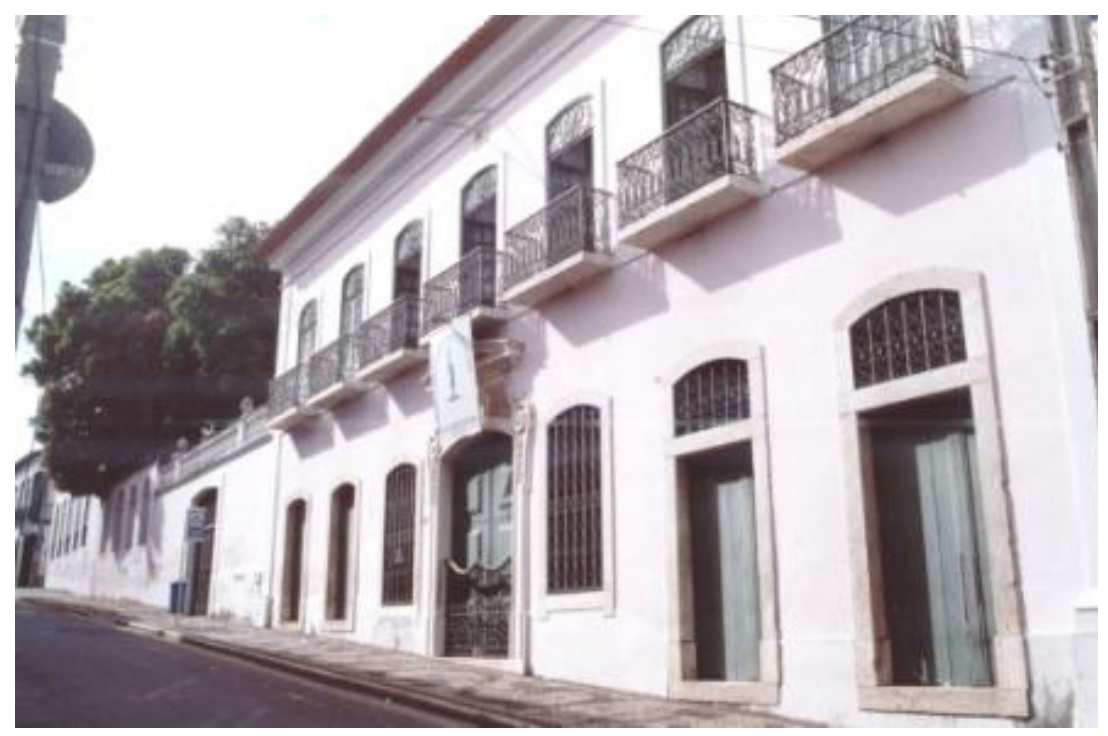

Figura 9a - Fachada do Solar, vista da rua. Fonte: Arquivo pessoal da autora.

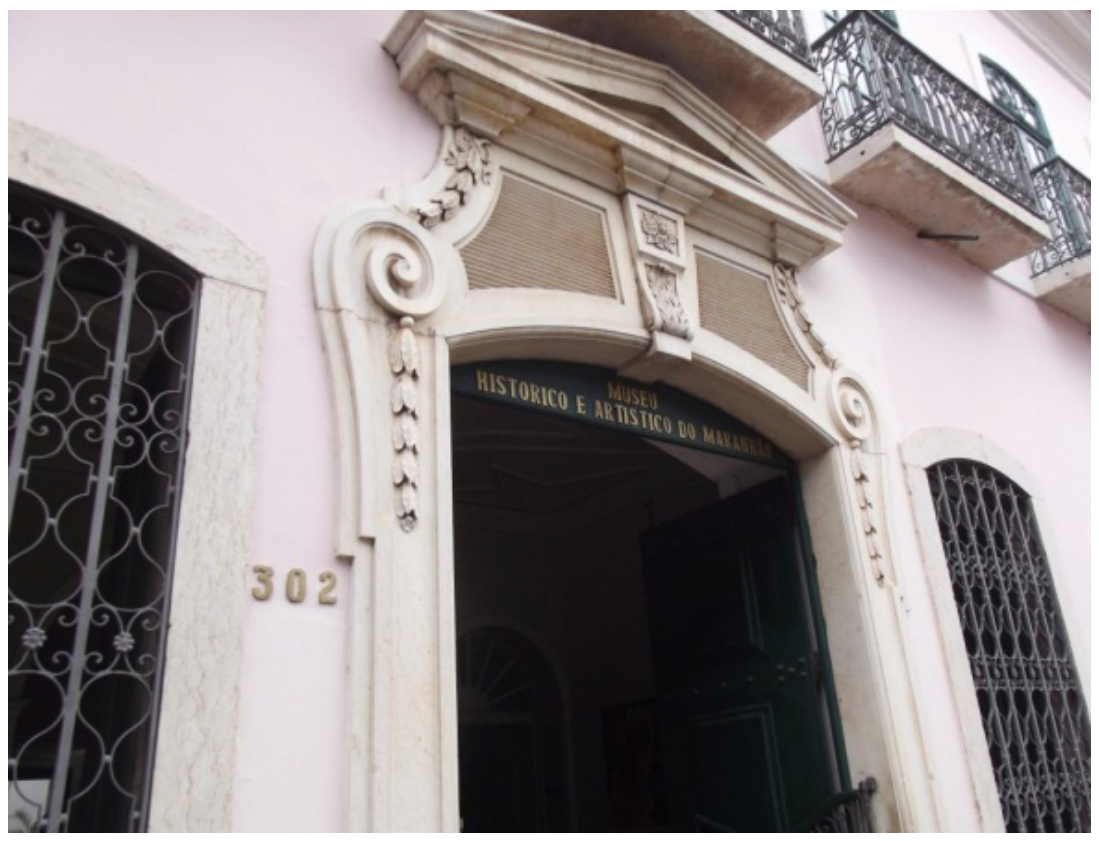

Figura 9b - Detalhe da Portada. Fonte: Arquivo pessoal da autora. 
janelas são rasgadas com balcões sacados de pedra e guarnecidos por gradis de ferro forjado.

\section{O programa}

O imóvel possui térreo e pavimento superior, além de um mirante. Embora hoje os espaços do Solar estejam adaptados para as instalações do Museu, o programa a ser apresentado aqui reflete o da edificação enquanto residência no século XIX.

O Solar é composto por vestíbulo, área para guarda de carruagens, charretes e cavalos, área para guarda de palanquins, teatro, escadas, pátio interno, jardins, cômodos de serviço, sala de música, sala da família, sala de visitas, biblioteca, quarto do casal, quarto da moça, quarto do rapaz, quarto do bebê, quarto de costura, alcovas e cozinha - sobre a distribuição desses espaços, falar-se-á adiante.

Sobre os tipos de cômodo existentes na habitação, muito se pode relacionar com a sociedade patriarcal, escravocrata, sexista e recatada da época.

A existência de ambientes destinados à guarda de carruagens, charretes e cavalos demonstra se tratar de uma residência de luxo, uma vez que as carruagens e charretes eram transporte da nobreza. O mesmo se dá para o Palanquim, que também tinha seu lugar assegurado. O palanquim era uma cadeira de passeio utilizada pela nobreza e carregada por escravos (figura 10). 


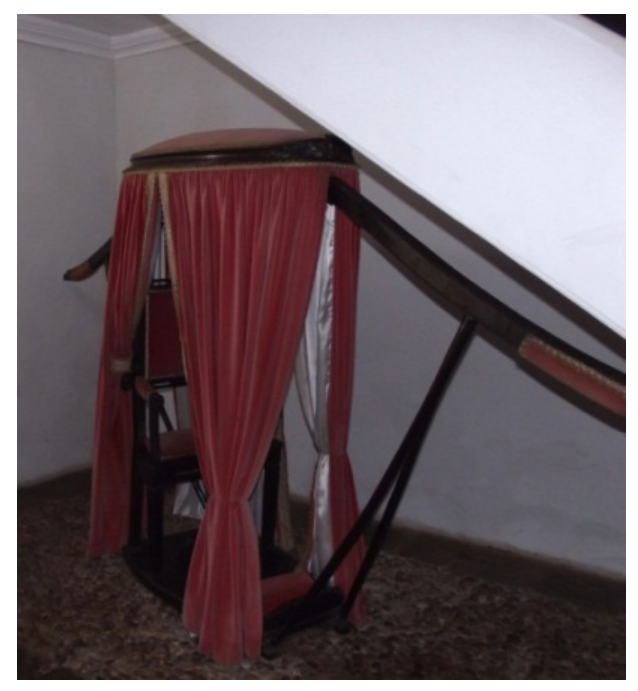

Figura 10 - Palanquim utilizado no século XIX, em exposição no MHAM. Fonte: Arquivo pessoal da autora.

Durante muitos anos, o pátio interno foi considerado como parte do serviço nos lares brasileiros, por ser um ambiente de livre circulação dos escravos nas casas oitocentistas. Era no pátio que se encontravam os poços que abasteciam as residências, como acontece no MHAM (figura 11). Aragão (2008) afirma que após a chegada da corte portuguesa ao Rio de Janeiro, no início do século XIX, algumas mudanças de hábitos e costumes foram percebidas. O uso de afastamentos frontais e laterais para melhor ventilar e dar privacidade aos cômodos permitiu a criação de jardins apenas ornamentais e contemplativos, separando-os das hortas e pomares, que ficavam na parte posterior do lote. Essa "setorização" do espaço verde da casa contribuiu para 


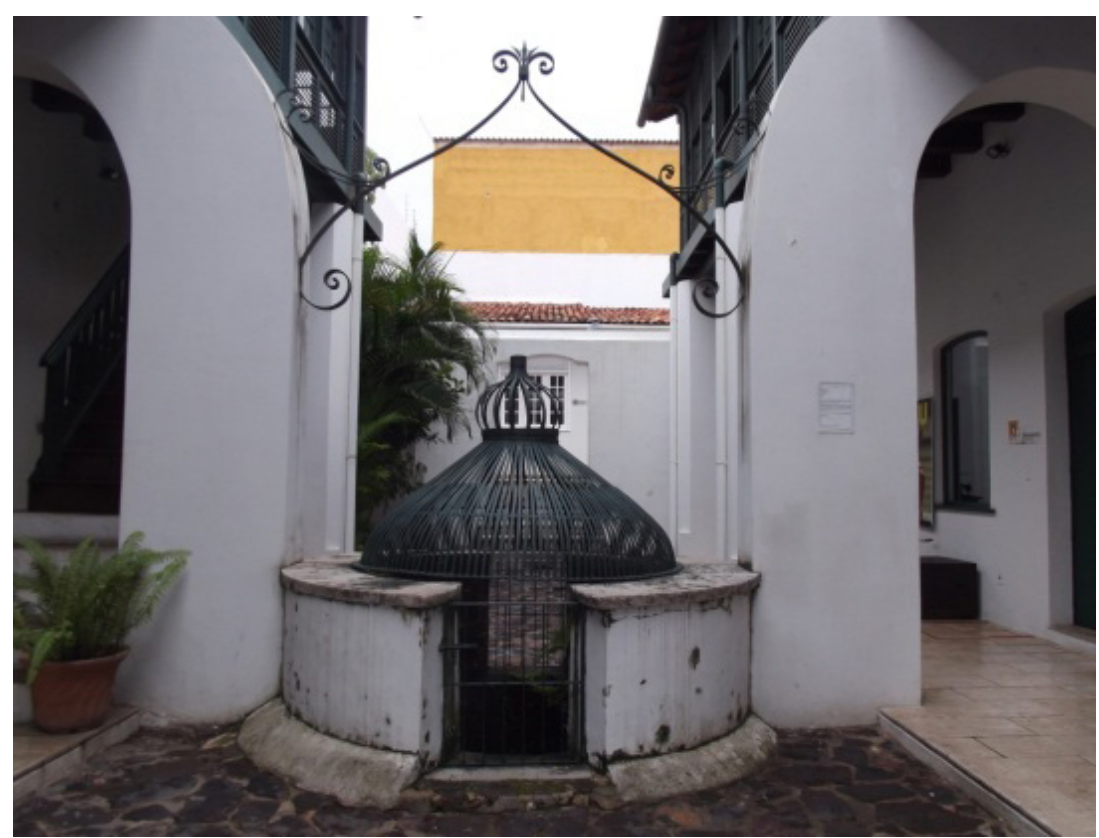

Figura 11 - Poço no pátio interno do MHAM. Fonte: Arquivo pessoal da autora.

o uso de serviço dos pátios e jardins posteriores.

Segundo Aragão (2008), posteriormente, no início do século $X X$, as casas mais abastadas se desprenderam totalmente dos limites do lote, sendo implantadas no centro do terreno e rodeadas por jardins, seguindo moldes europeus. Entretanto, o uso dos fundos e pátios internos pelos escravos para serviço já havia se consolidado.

Atualmente essa ideia ainda persiste, mas já existe uma forte tendência de integração do pátio posterior (hoje conhecido como quintal) com os espaços sociais. Esses espaços, que até então eram impensáveis para receber as visi- 
tas, vêem se transformando, cada vez mais, em áreas de lazer das residências brasileiras. Para Novaes (2013), essa nova função dos pátios residenciais se deve a vários motivos, como o crescimento desordenado das cidades e consequente insegurança e distanciamento para a locomoção, que incentivam a população a fazer seu lazer em casa.

Outro ponto é a falta de necessidade de espaços de circulação tão grandes para os "serviçais", uma vez que hoje, ainda nas famílias mais abastadas, o número de funcionários é menor que a quantidade de escravos que uma família nobre mantinha. Na obra "O Mulato", escrita em 1881, Aluízio Azevedo descreve a realidade da época nas casas da cidade, o que dá indícios do número de escravos por Solar, fora aqueles do sexo masculino, utilizados para os serviços pesados:

a criadagem de Manuel e Maria Bárbara constava não apenas de Brígida e Benedito, mas também de uma cafuza, já idosa, chamada Mônica, que amamentara Ana Rosa e lavava a roupa da casa, e mais de uma preta só para engomar, e outra só para cozinhar, e outra só para sacudir o pó dos trastes e levar recados à rua. $\mathrm{E}$ apesar desse pessoal, o serviço era sempre tardio e defeituoso (AZEVEDO, 1994).

Como não há mais escravos e os moradores tem cada vez menos ou nenhum empregado doméstico em casa, é necessário dar um novo uso ao local onde antes ficavam 
as dependências dos empregados e por onde eles transitavam. Ainda, as casas têm ficado cada vez menores e é preciso otimizar os espaços, tornando-os mais eficientes, considerando-se os costumes locais. Por exemplo, atualmente, uma família que recebe visitas para um churrasco no domingo (refeição que é, por hábito, simultaneamente preparada e consumida) acaba tendo dificuldades em utilizar ao mesmo tempo a cozinha, a sala de jantar e ainda uma área aberta da casa onde seria preparado o churrasco. Ao integrar a cozinha com a área externa, o preparo dos alimentos é facilitado. Como não há empregados e os próprios moradores e visitas irão preparar os alimentos, será preciso um "estar/jantar" nessa área externa onde se dará a reunião.

Novaes (2013) reconhece que essa questão acabou alterando a configuração arquitetônica de casas contemporâneas, onde a sala, antes voltada para frente da casa, voltou-se para o quintal, nova área de lazer da moradia.

No lugar de um espaço destinado apenas à realização de serviços domésticos, com varal para estender as roupas e cômodos para guardar badulaques, ele representa atualmente um dos espaços mais cobiçados da residência, onde famílias inteiras o usufruem como área de descanso, colocam em prática seus hobbies e revigoram as energias para encarar a correria da vida moderna... Principalmente em dias de sol, ele torna-se quase que um clube, onde amigos e familiares batem 

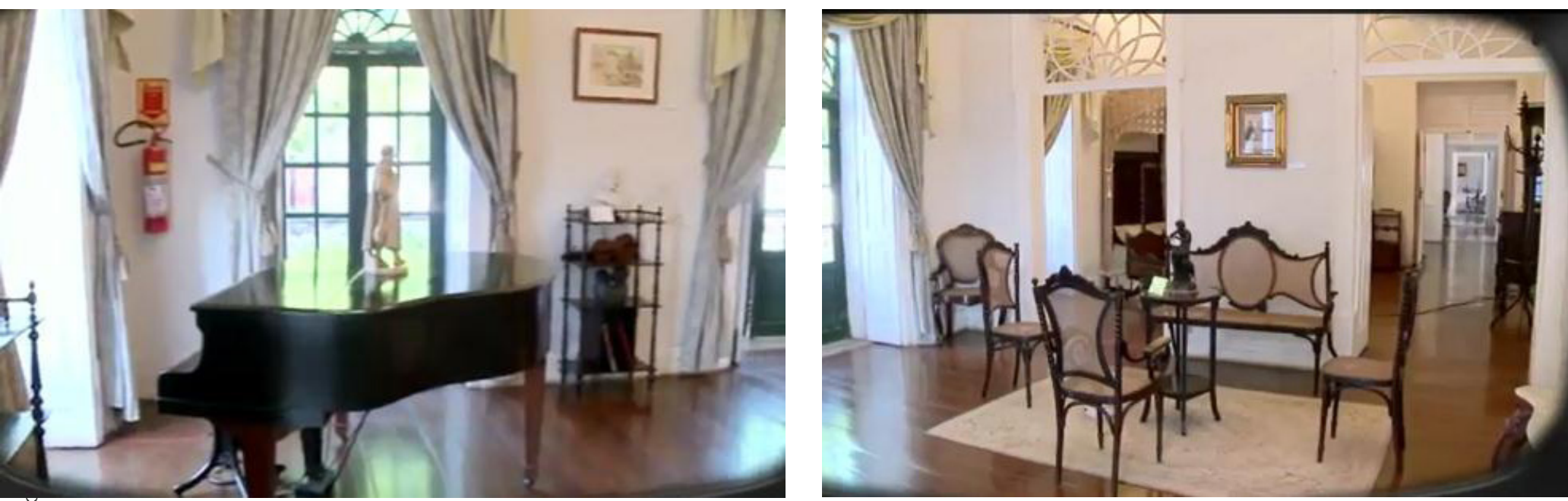

Figura 12a e 12b - Vistas da sala de música. Fonte: TVBRASIL (2015).

papo, aproveitam a piscina, fazem churrasco ou provam as delícias preparadas pelo anfitrião — ou por quem é eleito para colocar em prática os seus dotes culinários. Sem contar na possibilidade de momentos intimistas que são aproveitados para cuidar das plantas, dos animais de estimação, para ler um livro e até para ficar em silêncio apenas a ouvir os sons da natureza (NOVAES, 2013).

Por essa mesma razão, atualmente, é possível encontrar muitas casas brasileiras de classe média e alta com duas cozinhas. Quando os moradores não conseguem unir esses espaços a fim de facilitar as atividades, acabam construindo uma nova cozinha na área externa destinada ao lazer.

Quanto aos vários espaços destinados aos serviços e ao alojamento de escravos do solar Gomes de Sousa, eles são 
mais um exemplo da sociedade escravocrata oitocentista, cujos escravos realizavam as mais diferentes tarefas domésticas.

Ainda sobre os ambientes domésticos do Solar, segundo a TVBRASIL (2015), a existência de uma sala de música (figura 12a e 12b) entrega um comportamento feminino do século XIX: as mulheres, filhas de famílias ricas, viviam na cidade e seus hobbies eram tocar piano, cantar, falar francês e ir ao teatro, ao contrário do comportamento feminino do século XVIII, quando a mulher era mais rural, ligada à igreja e propensa aos trabalhos com escravos.

A existência de muitos quartos na casa reforça a constatação de uma família à época sob outros moldes, a de família por parentela, com agregados, como colocaram Mota (2008) e Costa (2013). Os solares podiam chegar a ter de 10 a 14 moradores.

A presença de um quarto de costura também revela um costume feminino da época.

Hoje, a alteração das famílias do conceito de clã para famílias nucleares alterou significativamente os espaços da casa, a começar pelo número de quartos existentes.

\section{O Zoneamento}

A implantação em "U" e o número de pavimentos favorecem o seu zoneamento que conta com área social, íntima 

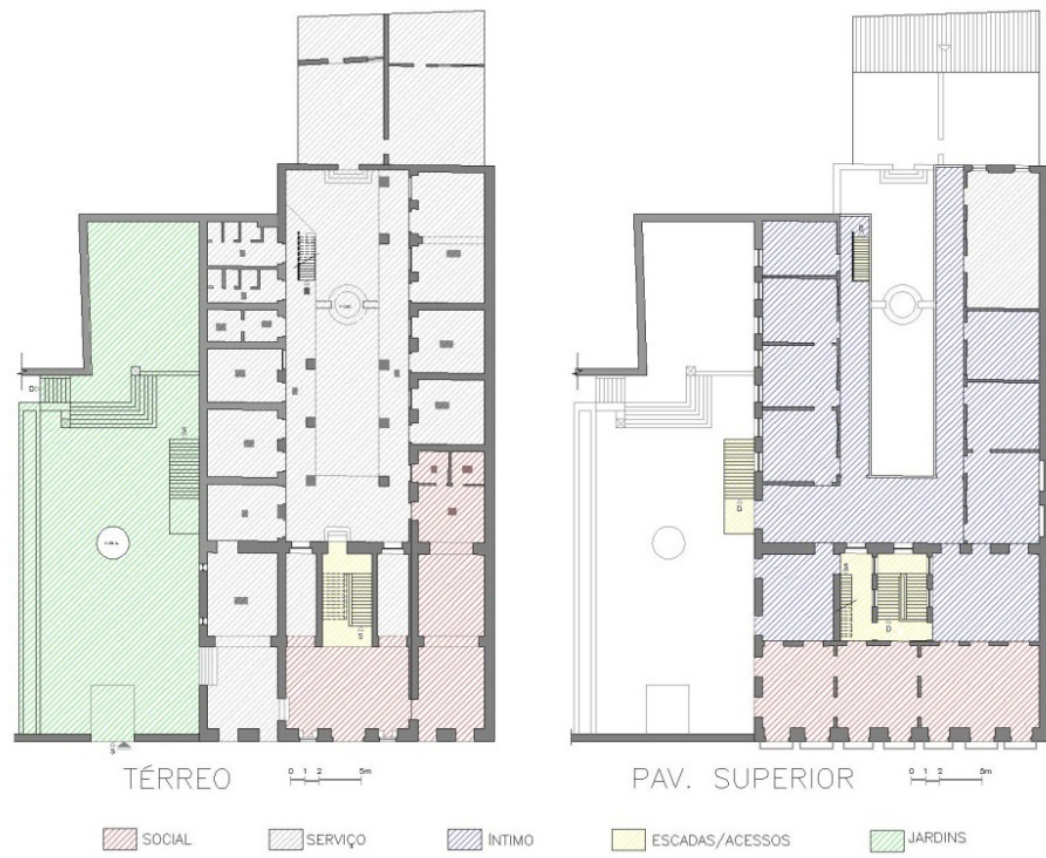

Figura 13 - Zoneamento do Solar Gomes de Sousa enquanto residência. Fonte: Elaborada pela autora.

e de serviço (figura 13).

O térreo é predominantemente usado para o serviço, com exceção do teatro existente, enquanto no pavimento superior ficam o setor íntimo e o social. Pode-se perceber como os ambientes eram interligados entre si.

Ainda para TVBRASIL (2015), o zoneamento do Solar também aponta uma série de costumes e hábitos de morar antigos, considerados pela sociedade atual como ultrapassados e até mesmo polêmicos.

O quarto masculino era o único da casa que não tinha liga- 


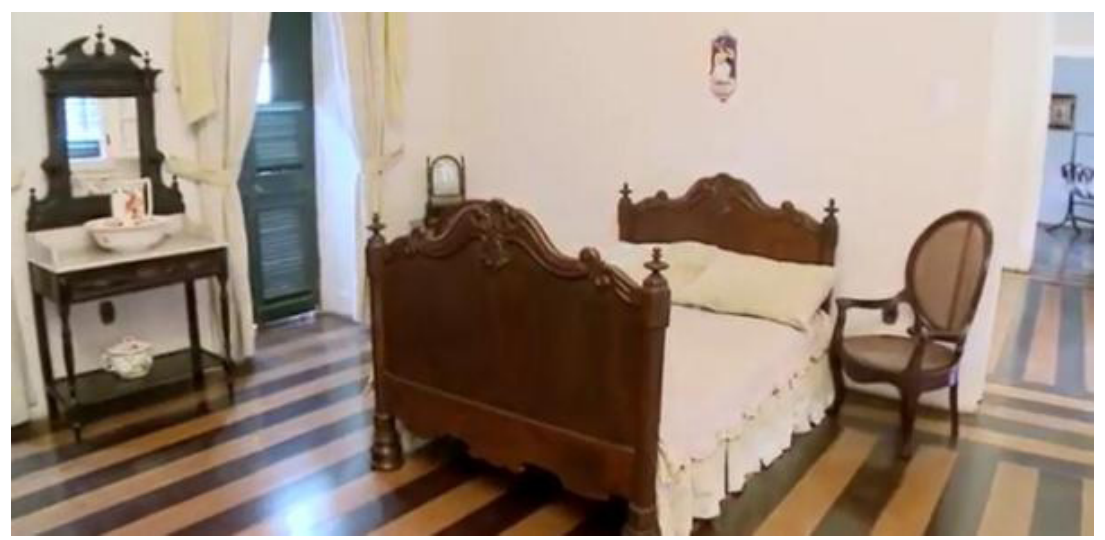

Figura 14 - Quarto da moça. Fonte: TVBRASIL (2015).

ção com os demais. A entrada ficava em frente à escada dos escravos, aos fundos, o que permitia o acesso de escravas durante a noite ao quarto do rapaz. Já o quarto da moça solteira (figura 14) era o mais próximo do quarto do casal, para que a mesma fosse vigiada pelo pai, pois ela precisava se manter "pura".

Ainda hoje, costumes sexistas são percebidos em lares brasileiros, cujo posicionamento dos quartos dos filhos sugere uma liberdade maior àqueles do sexo masculino.

O quarto do bebê, no solar, ficava entre o quarto da moça e o do rapaz, pois sua proximidade com o quarto da mãe não era necessário, uma vez que existia a escrava designada para cuidar apenas do recém-nascido. Por também amamentar a criança, essas escravas eram chamadas de "amas de leite".

Hoje, na sociedade brasileira, a figura da "babá", como são 
chamadas as empregadas domésticas que cuidam de crianças, ainda é uma forte realidade, tanto na classe alta como na média, em uma proporção bem maior do que a percebida em países onde a escravidão não existiu ou foi abolida mais cedo. Entretanto, algumas medidas sociais dos últimos governos vêm diminuindo sensivelmente sua presença, uma vez que a classe baixa está tendo acessos a mais renda e buscando empregos mais valorizados e com salários mais justos.

As salas "sociais" da casa, a de música, onde por vezes eram realizados saraus, a de visitas e a da família espelham a necessidade de reserva familiar, uma vez que seu posicionamento é estratégico, para que as visitas não adentrassem a casa. Estão posicionadas à chegada da escada e são interligadas entre si.

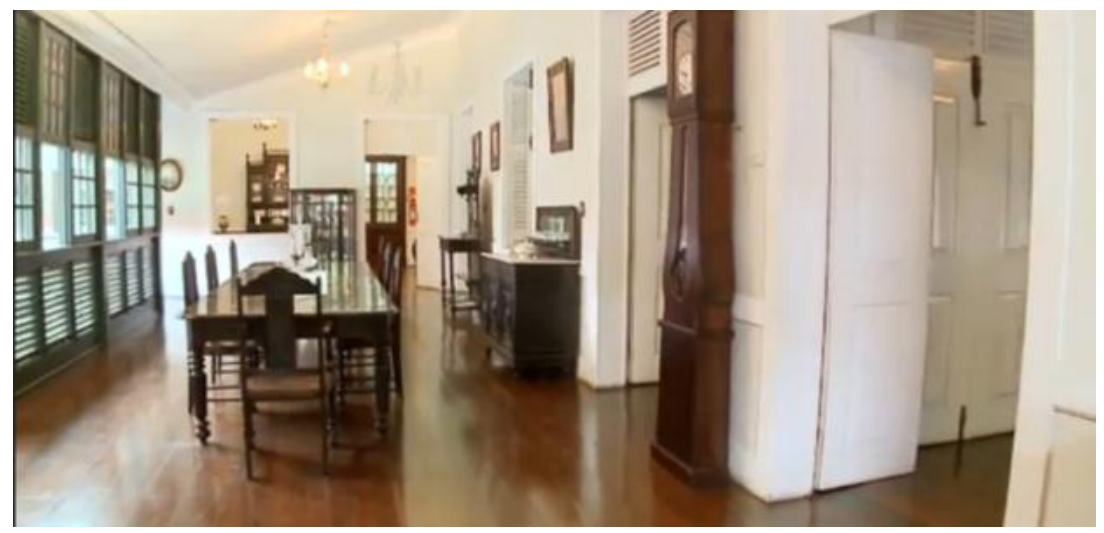

Figura 15 - Varanda e sala de jantar do Solar Gomes de Sousa. Fonte:TVBRASIL 
Na varanda, cômodo mais utilizado, era onde se encontrava a mesa de refeições (figura 15). Da varanda é possível ver todos os cômodos da casa. Sua posição estratégica permite que o patriarca possa controlar tanto os escravos fora da casa quanto a família dentro, como também certifica TVBRASIL (2015).

Embora os quartos de costura e de vestir estejam representados na exposição do MHAM, sua localização não é exata. Sabe-se, entretanto, que ficavam obrigatoriamente na zona íntima da casa.

\section{O mobiliário}

Os mobiliários de época existentes na exposição do MHAM não são originais da casa, mas foram doados por antigos moradores locais para que a exposição que retrata o modo de morar da nobreza fosse montada. É interessante observar como a influência europeia nos costumes da sociedade local é demonstrada em um mobiliário de modelo europeu que tenta copiar os espaços de morar além-mar.

Um dos mobiliários mais emblemáticos do MHAM é a Cadeira trono (figura 16), que consiste em uma cadeira de madeira com espaldar alto com um rasgo no assento. Abaixo do rasgo, havia um penico.

A cadeira era utilizada nos quartos, uma vez que a casa não dispunha de instalação sanitária. Os dejetos eram transportados por escravos 


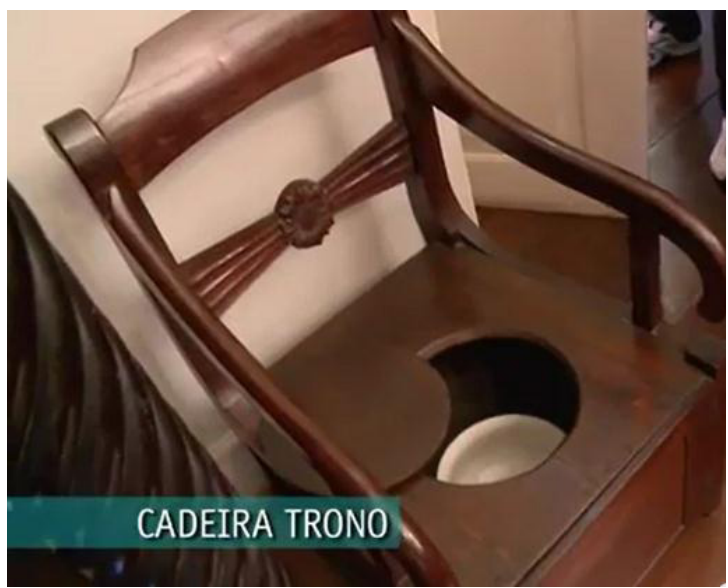

Figura 16 - Cadeira trono. Fonte: TVBRASIL (2015).

Todo o esgotamento sanitário era realizado pelos escravos, mais conhecidos como "tigres" que carregavam as latas de dejetos de dentro do quarto dos senhores até o térreo para posteriormente serem despejados na maré. Os escravos chamavam-se "tigres", pois durante o trajeto da casa até a maré carregavam as latas com os dejetos, no qual escorriam um líquido de tom amarelado em suas costas que ao longo do tempo marcavam a sua pele com faixas de cor amarelada que se assemelhavam à pele de um tigre (Luiz Phelipe Andrès apud Silva, 2013).

Outro mobiliário que atrai para um costume da época é o exemplo de berço do quarto dos bebês, um modelo austríaco, aberto nas laterais (figura 17a), com a cadeira da escrava representando o posto de guardadora. Como havia sempre a escrava cuidadora da criança por perto e acordada, não havia a preocupação de ela cair, ao contrário do 


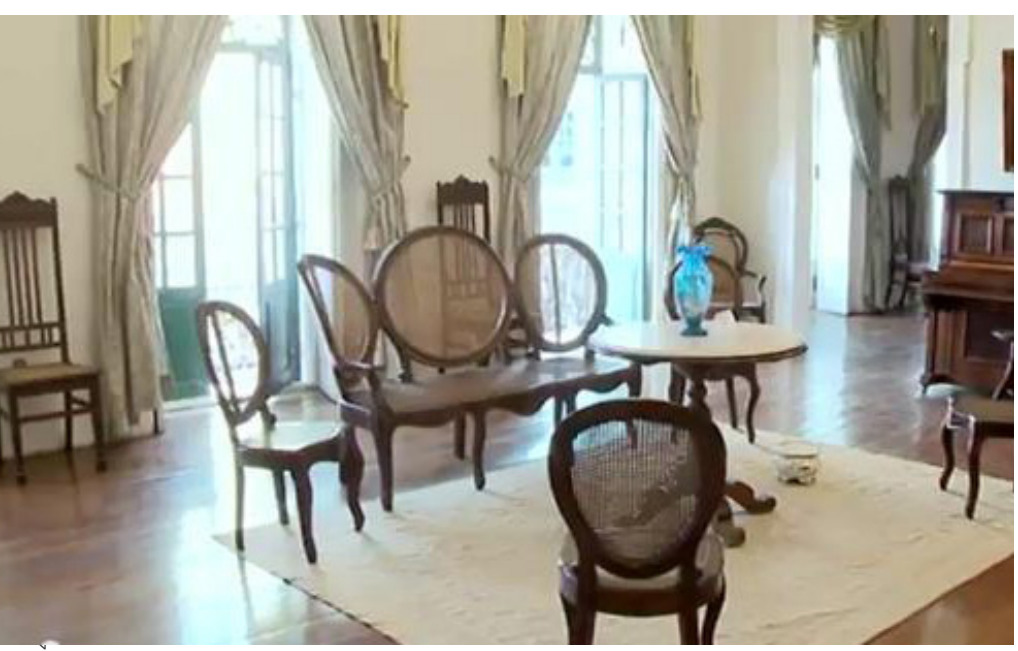

Figura 18a - Sala da família. Fonte: TVBRASIL (2015).

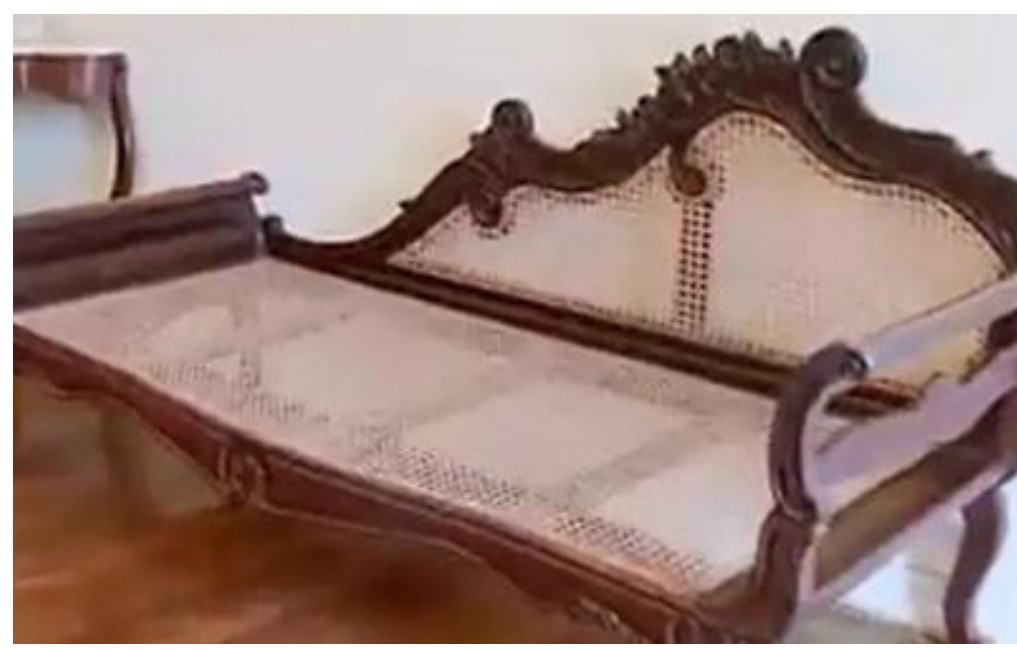

Figura 18b - Recamier. Fonte: TVBRASIL (2015).

É interessante colocar como o quarto do rapaz revela sua ausência em casa. Seu mobiliário é marcado pela simpli281 cidade e pela ausência da cama, tendo apenas uma rede. Segundo Costa (2013), os jovens da nobreza maranhense saiam de casa muito cedo para estudar, às vezes por volta dos 10 a 11 anos. Constantemente, após os estudos iniciais iam para a Universidade de Coimbra, onde ingressavam por volta dos dezesseis anos, ficando em casa apenas nos curtos períodos de férias.

Como utensílio que demonstra um costume de época, destacam-se as escarradeiras que presentes nos espaços sociais da casa, principalmente nas salas de receber, eram usadas por homens para cuspir. Na figura 18a, pode-se perceber um exemplar dessa ao chão, sobre o tapete. 


\section{Considerações finais}

Nesta pesquisa foi feito um recorte espacial da edificação e sua contextualização histórica. Em seguida a metodologia foi explicada e a análise realizada. Com a análise, verificouse que a edificação estudada, além de ser um exemplar da arquitetura Barroco Pombalina em São Luís, evidencia muito dos costumes coloniais do século XIX, em que a sociedade era patriarcal, sexista e escravocrata.

$\mathrm{Na}$ análise, foram consideradas a localização da edificação, o terreno, a implantação, a tipologia e composição volumétrica, o programa, o zoneamento e o mobiliário representativo da época.

A casa está em uma área tombada pela UNESCO e pelos governos federal e estadual e ocupa um terreno de pouco mais de $800 \mathrm{~m}^{2}$. Está implantada em formato de " $U$ " e ocupa todo o limite do lote.

É uma edificação considerada Barroco-Pombalina e possui um único volume com dois andares distribuídos em três setores: serviço, social e íntimo, que abrigam vestíbulo, área para guarda de carruagens, charretes e cavalos, área para guarda de palanquins, teatro, escadas, pátio interno, jardins, cômodos de serviço, sala de música, sala da família, sala de visitas, biblioteca, quarto do casal, quarto da moça, quarto do rapaz, quarto do bebê, quarto de costura, alcovas e cozinha. 
A partir da análise, entendem-se alguns dos costumes e tipologias de planta baixa e usos ainda presentes na sociedade ludovicense e brasileira, como a tripartição dos espaços de moradia em íntimo, social e serviço, a valorização dos pavimentos superiores em unidades residenciais, a proximidade das salas com a entrada das casas, o posicionamento dos quartos, com o quarto das filhas sempre mais próximo do quarto dos pais, a área de serviços escondida e ao fundo da edificação e o porquê dessas tipologias estarem sendo modificadas.

Conclui-se que o Solar Gomes de Sousa retratava os costumes e hábitos de morar de seus donos e que as transformações que vêem sendo praticadas nas habitações são reflexos de transformações ocorridas nos costumes e hábitos de morar da sociedade atual.

\section{Referências}

ARAGÃO, S. De. A casa, o jardim e a rua no Brasil do século XIX. Em Tempo de Histórias, Brasília, n.12, 2008.

AZEVEDO, A. O mulato. São Paulo: Ed. Ática, 1994.

COSTA, A. K. Uma "casa" irlandesa no Maranhão: Estudo da trajetória da família Belfort, 1736-1808. 2013. Dissertação de mestrado. Universidade Federal Fluminense, Programa de Pós Graduação em História. Niterói.

COSTA, C.; LIMA, R. Análise arquitetônica de uma residência moderna na cidade de João Pessoa/PB. $6^{\circ}$ Seminário DocomoMo Brasil. Niterói, 2005. 
DUAILIBE, J. D. A CASA MODERNISTA MARIA DALVA: o uso de seus espaços ao longo do tempo em face dos costumes da sociedade ludovicense. In: CONGRESSO INTERNACIONAL DA HABITAÇÃO NO ESPAÇO LUSÓFONO, 4., 2017, Covilhã. Anais... Covilhã: Universidade Beira Interior, 2017. 1 CD.

DUAILIBE, G. J. A excepcionalidade e a materialidade do Solar Gomes de Sousa: Um exemplar da arquitetura pombalina em São Luís. In: CONGRESSO ÍBERO- AMERICANO PATRIMÔNIO, SUAS MATÉRIAS E IMATÉRIAS, 1., 2016, Lisboa. Anais ... Lisboa: LNEC, 2016. 1 CD.

FUNDAÇÃO PROJETO RONDON. Monumentos históricos do Maranhão- Monumento Escultura Sacra. São Luís: FPR,1979.

NOVAES, M. Entrevista concedida à Revista Metrópole. O mundo no meu quintal. Metrópole, Campinas, edição eletrônica, 2013. Campinas, jul. 2013.

MOTA, A. S. "Estrangeiros" fazem fortuna no maranhão pombalino. In. ENCONTRO INTERNACIONAL DE HISTÓRIA COLONIAL, 2., 2008, Rio Grande do Norte. Anais... Rio Grande do Norte: Mneme - revista de humanidades, 2008.

SÃO LUÍS. Prefeitura. São Luís: Ilha do Maranhão e Alcântara. Guia de Arquitetura e Paisagem. São Luís: Prefeitura de São Luís, 2008.

SANTO, E. ; MARCELO, J. (Org.). São Luís: uma leitura da cidade. Prefeitura de São Luís / Instituto de Pesquisa e Planificação da Cidade. São Luís: Instituto da Cidade, 2006.

TVBRASIL. Conhecendo museus: Museu Histórico e Artístico do Maranhão. Disponível em: <http://tvbrasil.ebc.com.br/conhecendomuseus/videos>. Acesso em: 20 mar.2015. 
285 